DOI: 10.35757/RPN.2011.19.01

\title{
JUBILEUSZ \\ OSIEMDZIESIĘCIOLECIA URODZIN \\ PROFESORA JERZEGO HOLZERA
}

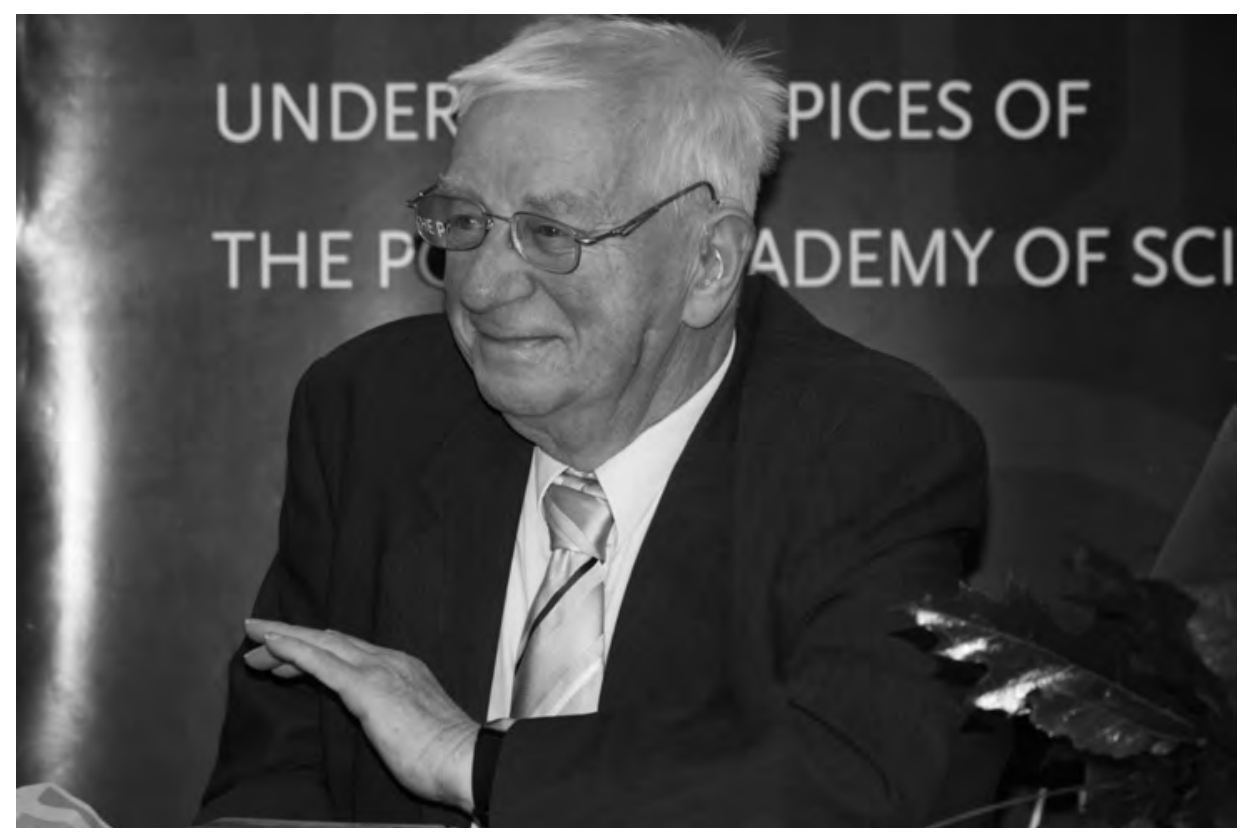




\section{Profesor Piotr Madajczyk}

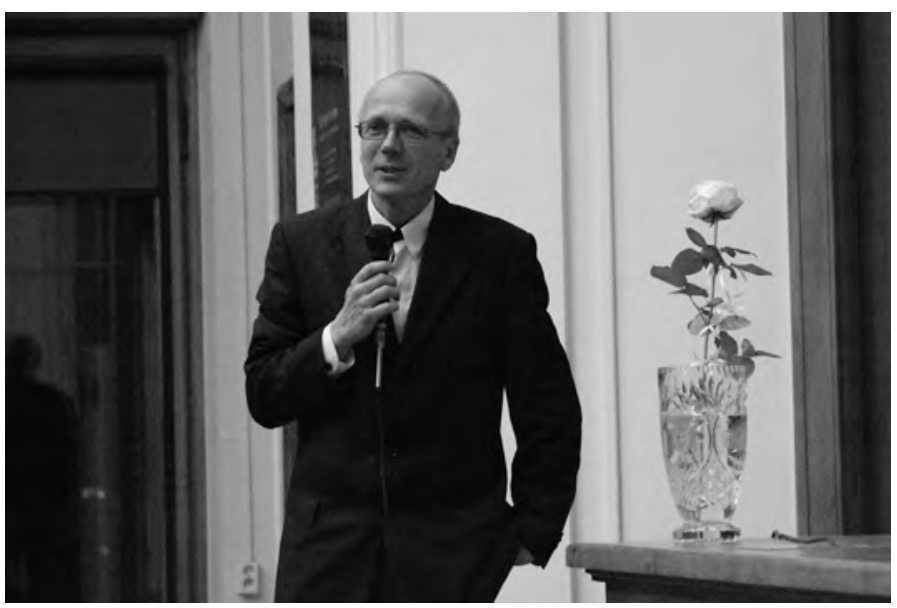

Szanowni Państwo, witam wszystkich serdecznie na uroczystości obchodów osiemdziesięciolecia Profesora Jerzego Holzera. Przypadł mi zaszczyt, jako obecnemu kierownikowi Zakładu Studiów nad Niemcami, którym Profesor przez wiele lat kierował, otwarcia naszej uroczystości. Zadanie to także niełatwe, bo jest on osobą znaną obchodził już jubileusze sześćdziesięcio- i siedemdziesięciolecia urodzin, a za każdym razem wiele mówiono o jego życiu i dorobku naukowym.

Nasze spotkanie składać będzie się z kilku części. Po otwarciu każdy z obecnych będzie mógł zabrać głos, nie ma tutaj żadnych ograniczeń, nie jesteśmy przecież na oficjalnej konferencji. W drugiej części poprosiliśmy o sformułowanie refleksji związanych z osobą i dorobkiem naukowym Jubilata trzech profesorów, dwóch z Niemiec i jednego z Polski: Dietera Bingena, Andrzeja Friszke i Klausa Ziemera. Każdy z nich ma przy tym pełną swobodę dokonania wyboru tego, o czym chce mówić, czyli tego, co uzna za najważniejsze. Można jeszcze raz przypomnieć, że nie jest to konferencja naukowa, a dzień refleksji nad osiemdziesięcioletnią drogą życiową i naukową Profesora. Zakończy naszą uroczystość rozmowa przy kieliszku wina i ciastkach.

Zacznę od krótkiego przypomnienia drogi życiowej Profesora. Należy do generacji, która urodziła się jeszcze w przedwojennej Warszawie, 24 sierpnia 1930 roku. Pięć dni później, i bez winy Jubilata, marsz. Józef 
Piłsudski przedstawił wniosek o rozwiązanie Sejmu. Prasa polska pisała zaś o świetnym odbiorze w Paryżu filmu Grety Garbo Ciało i diabet, znanego także pod tytułem Symfonia zmysłów. Potem przyszła wojna, spędzona w Warszawie. Jak wspominał, los oszczędził jego i członków jego najbliższej rodziny, nie oszczędził licznych krewnych. Nie oszczędził mu widoków codziennego okrucieństwa, przed którym uciekał w książki, także niemieckie.

Czuł się związany z tradycją PPS-u, ale w powojennej rzeczywistości wstąpił w wieku 18 lat do PZPR i pozostał w niej do końca lat siedemdziesiątych. Historyk, politolog, studiował historię na Uniwersytecie Warszawskim w trudnych latach 1950-1954 (w tym czasie urodził się profesor Bingen, rocznik 1952). Gdy zaczynał studia, oddziały południowo-koreańskie przekroczyły linię demarkacyjną aby 19 października 1950 roku zająć Phenian i wkrótce dojść do granicy z Chinami. Gdy kończył studia, Francja przeżywała swoją klęskę w Wietnamie. Wkrótce też urodził się najmłodszy z zaproszonych dzisiaj profesorów: Andrzej Friszke, rocznik 1956.

Pracę magisterką pisał u profesor Żanny Kormanowej, po studiach pozostał na Wydziale Historycznym Uniwersytetu Warszawskiego, wiążąc się z nim na długie lata, aż do roku 2000. Obronił doktorat o historii PPS w latach 1917-1919, prowadził badania nad historią Polski podczas I wojny światowej, pisząc razem z Janem Molendą Polskę w pierwszej wojnie światowej.

Wkrótce nadejść miał rok 1968, w którym Profesor był atakowany, ale nie został usunięty z Uniwersytetu. Rok później obronił kolokwium habilitacyjne. Jego zainteresowania badawcze przesuwały się, jak się to często historykom zdarza, ku czasom nowszym. Zajął się okresem międzywojennym, zarówno historią Polski, jak i historią powszechną. Analizował kryzys polityczny w Niemczech w latach 1928-1930, a wynikiem była książka Kryzys polityczny w Niemczech 1928-1930. Partie i masy. Wkrótce powstała także, i dzisiaj aktualna, Mozaika polityczna II Rzeczypospolitej, prowadził ponadto wykłady na Wolnym Uniwersytecie w Berlinie.

Coraz silniej angażował się $\mathrm{w}$ opozycyjną działalność polityczna, współpracował z KOR-em, publikował w pismach drugiego obiegu, był członkiem Towarzystwa Kursów Naukowych, a wkrótce zaangażował się 
w Polskim Porozumieniu Niepodległościowym. W 1980 roku tworzył „Solidarność" na Uniwersytecie Warszawskim, był internowany, a zarazem był autorem pierwszego opracowania historii „Solidarności” Solidarność 1980-1981. Geneza i historia. Równocześnie cały czas uczył na uniwersytecie, znajdując między innymi czas na przyłapanie autora tych słów na nieznajomości przyczyn niskiego poziomu rozwoju zaboru austriackiego.

Tytuł profesorski uzyskał dopiero w 1990 roku, po przemianach, które dokonały się w Polsce. $\mathrm{W}$ niczym nie zmniejszyło to jego aktywności: zaangażowanie w polsko-niemieckim pojednaniu, doradca Obywatelskiego Klubu Parlamentarnego ds. polityki zagranicznej, przewodniczący Forum Polsko-Niemieckiego, członek zarządu Fundacji Współpracy Polsko-Niemieckiej, członek Polsko-Niemieckiej Komisji Podręcznikowej. Naukowo zaangażował się w Instytucie Studiów Politycznych PAN, którego był przez jedną kadencję dyrektorem, w którym kierował przez lata Zakładem Studiów nad Niemcami oraz był założycielem i, rzecz jasna, redaktorem naczelnym pisma „Rocznik Polsko-Niemiecki”. Z tego okresu pochodzi także jego, docenione szeroko, syntetyczne spojrzenie na Komunizm w Europie. Dzieje ruchu i systemu władzy. Wykorzystując i podsumowując swój dorobek życiowy, stara się syntetycznie spojrzeć na europejską i polską historię najnowszą: Dwa stulecia Polski i Europy, Europejska tragedia XX wieku. II wojna światowa, Europa wojen 1914-1945.

\section{Profesor Wojciech Materski}

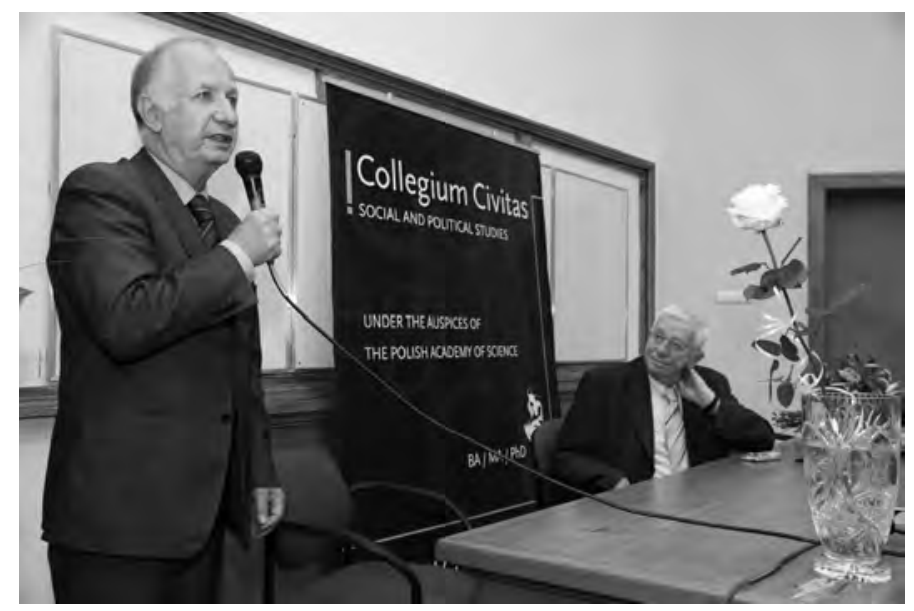


Szanowny Panie Profesorze, Drogi Jurku,

Twój wspaniały jubileusz to także wielkie wydarzenie $\mathrm{w}$ dziejach Instytutu, który również obchodzi swą rocznicę - dwudziestolecia powstania. Byłeś u jego zarania, tworzyłeś jeden z jego filarów - Zakład Badań nad Niemcami, kierowałeś placówką jako dyrektor, dziś z podziwu godną weną pracujesz na jej konto - wydając rok w rok nowe, znakomite książki. Budują one prestiż Instytutu, jego renomę naukowa, a zarazem dostarczają wielu punktów, na których fundowany jest nasz budżet. Chwała Ci za to i wielkie podziękowanie.

Państwo w większości znają Profesora Holzera od strony oficjalnej. My, pracownicy Instytutu, znamy Go także od strony mniej oficjalnej, jako wspaniałego kompana, który nie opuścił żadnego wyjazdu turystycznego, żadnego grzybobrania i - zapewniam o tym - był tam duszą towarzystwa. Przypomnę tylko, jak pojechaliśmy kiedyś na Ukrainę, a Profesor miał akurat ważną konferencję w Berlinie. Co zrobił? $\mathrm{Z}$ tego dalekiego Berlina, po wygłoszeniu referatu w pierwszym dniu konferencji, wsiadł w autobus i po całonocnej jeździe złapał nas jeszcze we Lwowie. Nie tylko do nas dołączył, ale też znakomicie uzupełniał przewodnika, przekazując nam frapujące ciekawostki o tym mieście, m.in. o ulubionym miejscu jego rodziców - Parku Stryjskim.

Chciałbym jeszcze powiedzieć prywatnie, że obchodzę mały jubileusz 45-lecia znajomości z Profesorem. W roku akademickim 1965-1966 profesor Holzer podówczas adiunkt prowadził na Wydziale Historycznym Uniwersytetu Warszawskiego na czwartym roku studiów stacjonarnych grupę ćwiczeniową w której i ja uczestniczyłem. Pamiętam jak nam wszystkim początkowo wydawał się surowy, wymagający. Dopiero z czasem poznaliśmy go od innej strony, jako człowieka z dużym poczuciem humoru. Do dziś mam w oczach, jak przepraszam za kolokwializm, przeczołgał całą naszą grupę ze znajomości geografii politycznej Polski. Powiesił na stojakach mapę i każdemu po kolei polecił znaleźć na niej Katowice. Nie uwierzycie państwo, ale nikt nie znalazł. Wówczas zwrócił się do nas ze słowami, które do dziś pamiętam. Studiujecie historię, macie odczytywać jej znaki z różnorakich przekazów. Każdy historyk powinien przede wszystkim przeprowadzić ich krytykę, zbadać okoliczności, w jakich powstały i wpływ tych okoliczności 
na ich treść. Gdybyście tak podeszli do sprawy i spojrzeli na metryczkę mapy, zobaczylibyście, że została ona wydana w 1952 roku. Wówczas przynajmniej co drugie $\mathrm{z}$ was byłoby się zorientowało, że $\mathrm{w}$ tym okresie miasto to nosiło przejściowo nazwę Stalinogród - dlaczego? Nie muszę chyba wyjaśniać. Nie tylko głęboka wiedza Profesora i umiejętność jej przekazywania, ale i takie anegdotyczne sytuacje budowały jego prestiż w naszym środowisku studenckim.

Jeszcze raz, Drogi Jubilacie, najlepsze życzenia i do zobaczenia za 10 lat, na kolejnym jubileuszu.

\section{Profesor Piotr Madajczyk}

Zanim przekażę mikrofon dalej, jeszcze przywołam życzenia przesłane przez panią profesor Gesine Schwan, która chciała być na spotkaniu, a którą Profesor zna od 1984 roku. Profesor Schwan, która jest osobą zaangażowaną nie tylko naukowo, ale także społecznie i politycznie w życiu w Niemczech, przesłała list gratulacyjny. Przeprasza, że już wcześniej przyjęła zobowiązania w tym dniu, które jej uniemożliwiają przyjazd do Warszawy. Dzisiaj jest w Poczdamie.

Niezależnie od pisma „usprawiedliwiającego nieobecność” (rzecz jasna w cudzysłowie) przesłała list z gratulacjami, serdecznymi życzeniami, podziękowaniami za współpracę, która między innymi zaowocowała $\mathrm{w}$ ramach jednego $\mathrm{z}$ projektów naukowych książką wydaną także po polsku o Demokratycznej i politycznej tożsamości. Składa życzenia, wspominając z dużą sympatią krytyczny stosunek Jubilata, jego umiejętność bardzo krytycznego spojrzenia na rzeczy, które pozostałym uczestnikom projektu wydawały się stać na mocnych nogach. Umiejętność wskazania, że wbrew pozorom są one trochę oderwane od rzeczywistości i należy to przywołać do porządku, wskazać właściwy kierunek.

Profesor Schwan przesyła list, który na pewno Jubilat także otrzymał. 


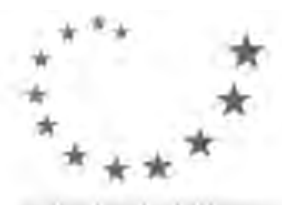

School of Governance

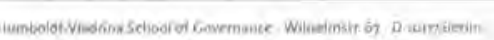

Institute of Political Studies

An Herrn Prof. Dr. Jerzy Holzer

ul, Polna 18/20

\section{Warszawa}

POLEN

Vorab Via E-Mail an: politic@isppan.waw.pl phome $+4930-20059710$ fax $\$ 49302005971$ id

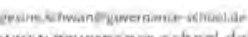
www. governancesschool.de

Die Prassiaentin

Prot. Or. Gesine genwart
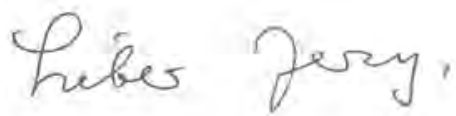

Berlin, den 26. August 2010

von ganzem Herzen möchte ich Dir zu Deinem großen Geburtstag gratulieren und Dir vielmals danken für alles, was Du in Deinem Leben anderen geschenkt hast - ganz persönlich mir und unseren Mitarbeitern im Projekt, aber auch den vielen Mitstreitern für eine bessere Gestaltung der deutsch-polnischen Beziehungen. In unserem Projekt über die demokratische politische Identität hast Du immer wieder mit Deinem reichen historischen Wissen unsere Gedanken auf ihre Haltbarkeit geprüft oder auch differenzierende neue Wege vorgeschlagen. Auch dafür bin ich Dir von Herzen dankbar.

Es tut mir sehr leid, dass ich am 28. September 2010 nicht nach Warschau kommen kann, um dort an einer Diskussion zu Deinen Ehren teilzunehmen. Ich hätte das sehr gerne getan, bin aber bedauerlicherweise schon eine andere Verpflichtung für diesen Tag eingegangen.

Ich wünsche Dir nun von ganzem Herzen alles erdenklich Gute und umarme dich, ebenso wie Barbara

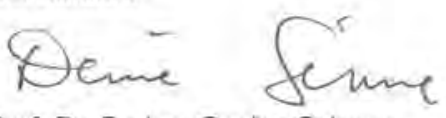

Prof. Dr. Dr. h.c. Gesine Schwan

HUMBOLOF.VIABRINA Sclicol of Covemán: 
Życzenia w imieniu Collegium Civitas składają profesor Jadwiga Koralewicz i profesor Edmund Wnuk-Lipiński

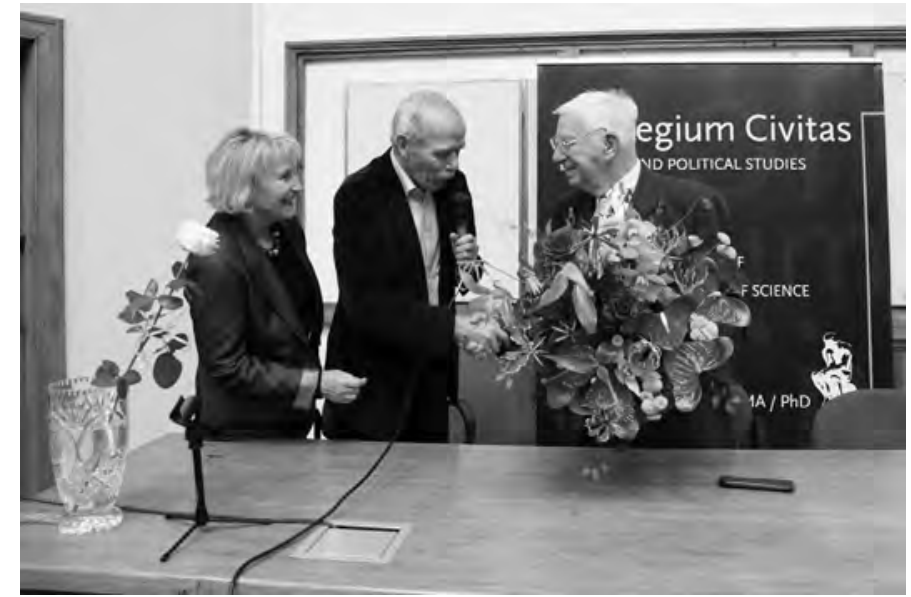

\section{Minister Władysław Bartoszewski}

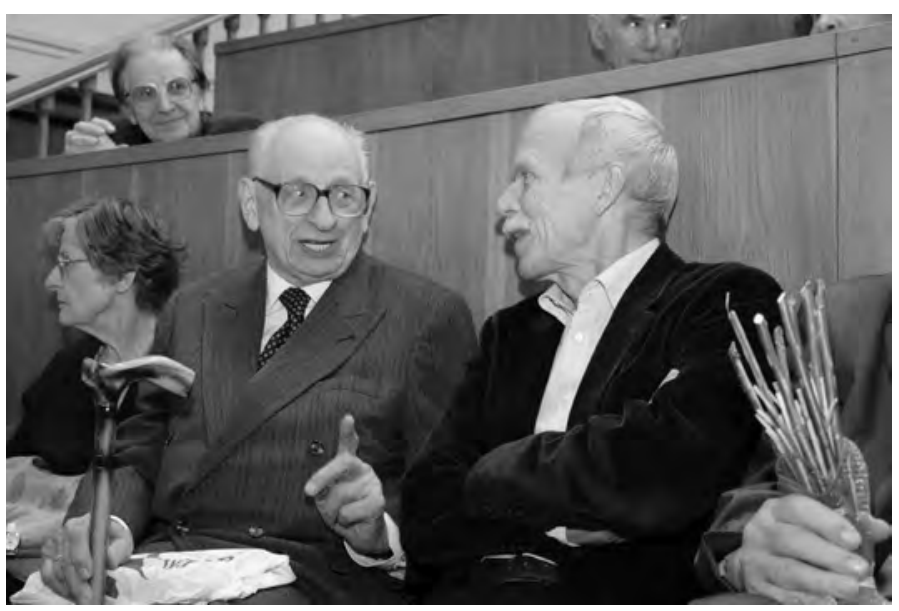

Kochany Jubilacie, drodzy Państwo, moje uprawnienia w tej sprawie nie są bardzo głębokie, gdyż znamy się niestety dopiero od około 20 lat, a są ludzie, którzy mają przyjemność, czasami radość, znania Jubilata dużo, dużo dłużej. Ale za to są moje uprawnienia bardzo specyficzne, dlatego że ja poznałem Jerzego Holzera w sytuacji, w której stałem się jego szefem, chociaż on wcale tego nie chciał. 
Mianowicie Jerzy Holzer przybył 22 grudnia 1981 roku helikopterem do ośrodka internowania w Jaworze koło Drawska na Pomorzu Zachodnim, gdzie wcześniejsza grupa była już od siedmiu dób. I został już powołany pewien ład, w którym poprzednicy zaszczycili mnie wyborem na starszego obozu, czy, jak niektórzy twierdzili, turnusu. Otóż, kiedy Jerzy Holzer z innym kolega przybyli 22 grudnia, w tych pierwszych dniach ogólnego pomieszania i stanu wojennego, do Jaworza, to przybył już na gotowe, bo tam był nieźle zorganizowany ład, oparty o demokratyczną autoryzację, gdyż do dziś wspominam ze wzruszeniem, że moje wyniki wyniosły przy wyborze jawnym, ale wolnym, Pań i Panów, którzy wtedy byli w jednym obozie, $100 \%$. Czyli przewyższały przeciętne wyniki Józefa Stalina które były 98,99\%. Ja zostałem wybrany $100 \%$ głosów, chcąc nie chcąc byłem szefem Jerzego Holzera jako starszy obozu.

Ja wiekiem byłem najstarszy, bo miałem lat 60 . Inni tyle nie mieli, ale byli tam naprawdę ludzie powszechnie znani, że wymienię przede wszystkim Bronisława Geremka. Znani w podwójnym znaczeniu, jako historycy, ludzie i działacze. Tadeusz Mazowiecki, który tam był, też nie był historykiem, ale też był nie mniej znany. Najmłodszymi naszymi historykami w obozie byli Marek Barański i Bronisław Komorowski. To byli nasi chyba najmłodsi koledzy, niewiele lat po zakończeniu studiów, czyli było to wyjątkowe środowisko, a ja czułem się niesłychanie zobowiązany i dumny, że mam takich podopiecznych, bo tak to oczywiście rozumiałem i traktowałem. Oni też oczywiście z tym się liczyli i tak to rozumieli i tak to traktowali, że mam być czynnikiem pośredniczącym.

Chciałbym powiedzieć, że zupełnie uchylam się od oceny dorobku naukowego Jerzego Holzera, z którego korzystałem w życiu, szczególnie gdy chodziło o problemy najnowszej historii politycznej Polski, to znaczy międzywojennej i lat wojennych. Bardzo dużo korzystałem, bo jak na warunki cenzury PRL-u to, co się udało Mu wtedy już ogłosić, było do użytku. Szczególnie książka, która była przeglądem rozszerzonym, mozaiką polskiego życia politycznego i partyjnego II RP. Łatwo było znaleźć źródła jej odniesienia i to było bardzo użyteczne. Zalecałem moim studentom na KUL-u tego typu publikacje, a miałem 
wśród studentów takie perełki jak Bogdana Borusewicza, Janusza Kurskiego i innych. Wymieniam tylko dość powszechnie znanych i wiem, że książki czy też artykuły niektóre Jerzego Holzera mogły służyć uczciwym studiom na KUL-u, który dawał niezależność w zakresie dawania takich zaleceń studentom ze strony prowadzącego seminarium. W małym gronie właśnie Holzer należał raczej do tych wyjątkowych historyków, gdyż nie sztuka było pisać o XVI wieku, ale o historii dziejów najnowszych. Tak, żeby z czystym sumieniem można było to zalecać. Tak więc nie będę oceniał ani jako praktyczny wykładowca, ani użytkownik Jego twórczości, ale chcę powiedzieć o czymś bardzo osobistym, bo to jest osobisty Jubileusz. Każdy ma swoje osiemdziesięciolecie, jeśli je ma. Jan Nowak-Jeziorański, który zawsze mi wytykał, że jest ode mnie starszy o 8 lat, gdy skończyłem lat 80 , to mi powiedział publicznie: mój drogi życie zaczyna się po osiemdziesiątce. Nie wiem, czy tak jest, czy się zaczyna czy zacina, powtarzam słowa klasyka, którym jest nieboszczyk od pięciu i pół roku, Nowak-Jeziorański, doświadczony człowiek, życzliwy takim ludziom jak my.

Muszę powiedzieć, że dla mnie zawsze były ważne stosunki człowieka z człowiekiem. Tak pozostało do dziś, bo niczego bardziej się nie brzydzę niż pewnego nastawienia, pewnego pesymizmu, podejrzliwości, niechęci, uprzedzeń, które rodzą ksenofobię, a ta rodzi nieżyczliwość, nienawiść. Wszystko to razem, z obserwacji mojego życia, jest straszne. Na ten temat chciałbym powiedzieć, że znalazłem pewną długość fali dowcipu dyskretnego, ale głębokiego i bardzo inteligentnego, Jerzego Holzera, którego bliżej poznawałem w obozie. A wcale niekoniecznie wszyscy intelektualiści są szalenie dowcipni, tak wcale nie jest i nie musi być, ale On właśnie był człowiekiem dowcipnym i tak się złożyło, że ja obchodziłem w obozie sześćdziesięciolecie. Ze względu na to, że Jurek obchodzi osiemdziesięciolecie ja mu przyniosłem moją najnowszą książkę, której jeszcze nie ma w księgarniach, z dedykacja która brzmi „Drogiemu Jerzemu Holzerowi w wieku 80-lecia z wdzięcznością losowi, że brał udział w moim zgrzebnym 60-leciu w warunkach internowania 1981-1982 oddany". Tutaj masz mój Drogi Jurku, a dla obecnych, żeby im było trochę weselej, chciałbym powiedzieć, że kiedy sześćdziesięciolecie obchodziłem, to internowani - którzy byli tam 
$\mathrm{w}$ warunkach internowania $\mathrm{w}$ Jaworzu mniej więcej na poziomie swobód $\mathrm{w}$ oflagach niemieckich, to znaczy to nie było ani więzienie, ani katownia, ani archipelag Gułag, ani stalinowska piwnica, bardziej dla rodzin niż dla nas były to trudne warunki, ja mogłem swobodnie czytać, dyskutować i wykorzystywaliśmy do oporu te warunki - koledzy postanowili zrobić coś w rodzaju pamiątkowego tekstu, który jest o tyle rzadki, że był w jednym egzemplarzu. No ale Roman Zimand, po zwolnieniu z obozu, znalazł formę, żeby powielić to wydanie w 1982 roku już. Wszedł do obiegu nieautoryzowany tekst, który kilkudziesięciu kolegów, w tym Tadeusz Mazowiecki i Jerzy Holzer, każdy dla siebie i imiennie wypełniło swoimi myślami i uwagami. Myśli i uwagi Holzera mówią tyle o nim, że warto jest to, co napisał, niezbyt długie, przeczytać, bo to miało być o mnie, ale to było to, co pozostaje do dziś bardzo drogie.

Tak jest Jurku, muszę Ci to wyznać, jak mężczyzna mężczyźnie, chociaż nie jest to modne, muszę Ci to wyznać, jesteś dla mnie człowiekiem drogim. Otóż napisał w 1982 w lutym z okazji mojego skromnego sześćdziesięciolecia o światopoglądzie optymizmu katastroficznego, czyli wykład z dziejów historiografii polskiej XX wieku. „WB wykładał i publikował głównie o XX wieku, poczynając od lat 40., uprawiając historię zajmował się dziejami kolejnych katastrof i udowadniał, że nie ma takiej katastrofy, która nie osiagnęłaby poziomu dna. Od takiego dna możesz się odbić, byle tylko nieznana chwila dojścia do dna zastała podmiot historii, za tego rodzaju podmiot uważał człowieka, na prostych nogach nie zaś na klęczkach. Twierdził, że nawet najzdolniejsi akrobaci nie potrafią skoczyć z pozycji klęczącej. Teza ta nie była przez niego dokładniej wydedukowana, ale wydaje się wysoce prawdopodobne, że nie da się nigdy z góry przewidzieć, kiedy i na jakiej głębokości dotrzemy do dna. Wielu optymistów niekatastroficznych zwraca uwagę na częste złudzenia tzw. pseudodna. Wskazywał, że łagodne odbicie od owego pseudodna grozi upadkiem z wysokości kilku pięter, co poważnie zakłóciłoby postawę optymistyczną gdyż optymizm pozbawiony luk zakłada, że zawsze może być gorzej. Głosząc optymizm totalny, płynący z przeświadczenia o potencjalnej wyższości dnia dzisiejszego nad dniem jutrzejszym, choć także nieuchronnej wyższości któregoś 
z jutrzejszych, być może dość odległego, nad dniem dzisiejszym, tylko w historii mógł osiągnąć swego rodzaju integralną postawę światopoglądową optymizmu katastroficznego. Skoro wśród współczesnych historyków postawa taka nie była powszechna, sądzić należy, że w WB się działo coś jeszcze, abstrahując od faktu, że sam siedział dość często, jednak zajmiemy się tym na następnym wykładzie". Jak można nie kochać tego człowieka.

\section{Profesor Andrzej Friszke}

Drogi Jerzy, drogi Jubilacie, mam do przeczytania list, stąd się zgłaszam do zabrania głosu. Jest to list, który przywiozłem od Andrzeja Krawczyka, ambasadora Polski w Bratysławie, który jest uczniem naszego dzisiejszego Jubilata. Pozwolę go sobie przeczytać:

„Szanowny Panie Profesorze,

Rozpocząłem tak formalnie, ale właściwie należę do generacji, która mówiła do Pana i o Panu przez kilkanaście lat Panie Docencie i już wtedy wiedzieliśmy, że ten tytuł, który z powodów politycznych nosił Pan przez wiele lat, brzmiał $\mathrm{w}$ tym przypadku bardzo specjalnie, to był nasz dowód uznania. Kiedy ktoś powiedział, Docent robi spotkanie, było jasne, o którego Docenta chodzi. W innych przypadkach zawsze dodawało się nazwisko. Przyszedłem na Pańskie seminarium na początku lat siedemdziesiątych, właśnie kończył się czas mozaik politycznych drugiej Rzeczpospolitej. Idąc za Panem przechodziliśmy do świata problematyki powszechnej europejskiej. Pańskie analizy ideologii, struktury, kształtu, uzależnień, relacji między sferą wydarzeń a sferą mentalności były ważnym elementem naszej wówczas kształtującej się świadomości i wrażliwości intelektualnej. Otwierał nas Pan na tematykę niemiecka, co nie było tak prostym i oczywistym dla młodzieży wychowanej w obolałej jeszcze po nazistowskiej okupacji Polsce lat sześćdziesiątych. A ci, którzy mieli przyjemność uczestniczenia w Pańskich obozach naukowych i rozmowach do późnych godzin nocnych, kształtowali przy Pana pomocy coś więcej: swój światopogląd i rozumienie procesów życia społecznego. Szanowny Panie Profesorze, czcigodny Jubilacie i nasz nauczycielu dzięki za wszystkie rozmowy w Instytucie Historycznym, w Bartoszycach, w Rostoce w Tatrach, w Berlinie 
i w Moguncji. Mam nadzieje, że następne rozmowy przed nami i już się na nie cieszę.

Andrzej Krawczyk

Ambasador Rzeczpospolitej Polskiej na Słowacji

Adiunkt Uniwersytetu Warszawskiego

Wykładowca Historii Najnowszej Polski na Uniwersytecie Komeńskiego w Bratysławie".

\section{Profesor Janusz Żarnowski}

Proszę Państwa, nie zamierzałem zabierać głosu, ale w toku dzisiejszego spotkania uświadomiłem sobie, że jestem tutaj spośród Państwa i w ogóle w Warszawie i w ogóle w Polsce człowiekiem, który chyba najdłużej zna Jerzego Holzera. Poznałem go w roku 1950 na jesieni, kiedy rozpoczynałem studia w Instytucie Historycznym Uniwersytetu Warszawskiego. Jest to, w tej chwili sobie uświadomiłem, 60 lat. To spory szmat czasu, byłoby nieprzyzwoite gdybym nie zabrał tutaj głosu.

Chcę złożyć memu koledze życzenia. Przez pewien czas żyliśmy w bardzo dużej przyjaźni, wiele lat później nasze drogi rozeszły się $\mathrm{w}$ jakimś sensie zawodowym. Jerzy Holzer jest dzisiaj politologiem, a ja zostałem nadal historykiem, chociaż proszę Państwa przez wiele lat wykładam, czy wykładałem, przedmioty politologiczne, więc nie czuję się osamotniony. Chcę tylko powiedzieć, wtedy w tym strasznym, czarnym okresie stalinizmu w roku 1950 myśmy przyszli do Instytutu Historycznego Uniwersytetu Warszawskiego, obaj skończyliśmy, ja w roku 1954, a ty chyba też w 1954 roku. Wtedy był wprowadzony idiotyczny podział na studia, nie nazywano tego licencjackimi tylko pierwszego i drugiego stopnia. Potem, po 1956 roku, rozsądnie to zlikwidowano, a teraz oficjalnie w Unii Europejskiej wróciło to - studia licencjackie, ale mam nadzieję, że to też minie. Instytut Historyczny Uniwersytetu Warszawskiego, w którym przewodził Tadeusz Manteufell, Aleksander Gieysztor, Stefan Kieniewicz. Oni naprawdę byli przedstawicielami, którzy uczyli nas historii najnowszej, oni nadawali ton. Ja tak sądzę, że myśmy przez te kilka lat studiów uzyskali naprawdę przyzwoite podstawy dalszej działalności nauko- 
wej, powiedzmy sobie w duchu prawdziwej nauki, bo to się jakoś tak złożyło, że ten system stalinowski przesiąkał dopiero w roku 1950, 1951. Pamiętacie Państwo, ta słynna konferencja otwocka, notabene teraz byłem na drugiej konferencji otwockiej, ale ta pierwsza to była na przełomie 1951-52. Zanim system stalinowski przesiąkł do Instytutu Historycznego Uniwersytetu Warszawskiego, myśmy jeszcze studia skończyli. Potem szybko nastąpił odwrót największego stalinizmu, krótko mówiąc, dla nas te studia to było coś bardzo dobrego, myśmy się czegoś nauczyli, myślę, że mnie i dzisiejszemu Jubilatowi w dalszej pracy to się bardzo przydało.

Nie będę komentował jego dalszej pracy naukowej. Od ścisłej historii przeszedł poprzez historię powszechną do prac o charakterze historii współczesnej czy politologicznej. To już mniej interesujące... Składam naszemu przyjacielowi, koledze, wybitnemu uczonemu najlepsze życzenie, aby nie za 10 lat, ale za 20 lat spotkać się na podobnym Jubileuszu. Chcę jeszcze, ponieważ jestem wybrany przez historyków na drugą kadencję przewodniczącym Komitetu Nauk Historycznych PAN, w imieniu tego Komitetu, czyli w imieniu społeczności historycznej, złożyć Tobie najlepsze życzenia zdrowia, dalszej działalności naukowej, i w ogóle wszelkiej pomyślności.

\section{Profesor Jerzy Tomaszewski}

Proszę Państwa, Jerzy mnie zmobilizował, żebym też zabrał głos, jako że wprawdzie nie znamy się z Jurkiem tak długo, moja pamięć nie jest najlepsza, szczerze powiedziawszy mam wrażenie, że się znamy od zawsze. W każdym razie od niepamiętnych lat wysoko, Jerzy, ceniłem Twoje prace, a ponieważ zbliżyły nas zawodowo przynajmniej zainteresowania okresem międzywojennym, chcę tutaj powiedzieć dobre słowo o książce, która, mam wrażenie, trochę zostaje zapomniana, natomiast do której sięgam dość często, stoi na półce w dogodnym miejscu, żeby do niej sięgnąć. Chciałbym podziękować za tomik o partiach politycznych w Polsce międzywojennej, uważam, że do dzisiaj jest bardzo użyteczny, pożyteczny, pouczający mimo że ma wiele lat i serdecznie dziękuje za to i życzę 120 lat... 


\section{Adam Michnik}

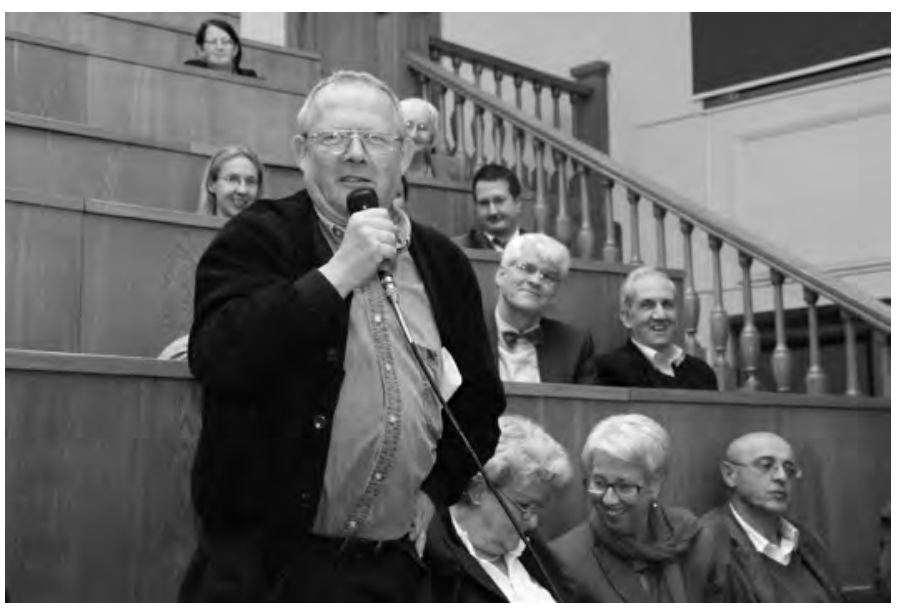

Profesor Żarnowski powiedział, że nie komentuje ekscesów Jerzego Holzera, jakimi było jego włączenie się do polityki, zamiast klasycznych prac historycznych. Jako ten, który jest współwinowajcą jego ekscesów, chciałem powiedzieć, że jestem Mu szczególnie wdzięczny za te ekscesy, dlatego że szanowanych historyków, których Pan Profesor wspominał, my w Polsce mieliśmy dużo, polska nauka historyczna miała szczęście do wybitnych bardzo uczonych. Natomiast takich historyków, którzy umieli jako pierwsi przekroczyć ten Rubikon pisania pod cenzurą, którzy zdecydowali się pisać bez cenzury, zdecydowali się na stanowczą odmowę cenzurowania swoich tekstów, takich historyków było bardzo, bardzo niewielu, a Jurek Holzer był wśród pierwszych i poczytuję sobie za zaszczyt, że ja odwiedziłem ich mieszkanie, Basi i Jurka, i namówiłem Jurka, żeby pisał do podziemnych gazet, co wtedy było kryminałem, więc jeżeli profesor Żarnowski tego nie komentuje, to ja z zachwytem to komentuję i życzę Ci wszystkiego dobrego.

\section{Profesor Piotr Madajczyk}

Za chwilę poproszę o zabranie głosu profesora Dietera Bingena, Andrzeja Friszkę i Klausa Zimera. Oczywiście Jubilat może w dowolnym momencie przejąć mikrofon. 


\section{Profesor Jerzy Holzer}

Proszę Państwa, kilka słów z mojej strony, może będzie ich trochę więcej niż kilkanaście, może kilkadziesiąt.

Jubilat, gdy słyszy wszystkie pochwały pod swoim adresem, myśli sobie: jestem genialny, miły, albo na odwrót myśli sobie: no tak, słyszę te pochwały, przecież wiem, że nie jestem ani taki genialny, ani taki miły. To znaczy, że tkwi we mnie jakiś kawałek oszusta. Jest to diabelska alternatywa. Ja staram się nie wchodzić ani w jedna, ani w drugą rolę. Mam natomiast takie poczucie, że właściwie mam 80 lat trochę przez historyczną pomyłkę. Ponieważ ja lubię zaglądać w statystyki, statystycznie rzecz biorąc ja powinienem od 70 kilku lat nie żyć. No może od 60, ale jakoś przeżyłem, istnieję i mam te 80 lat. Co stanowi mój dorobek proszę Państwa? Książki. Teraz mało kto czyta książki, natomiast za 20 lat będzie tylko fragment $\mathrm{w}$ jakieś książce historiograficznej i tam będzie mowa o tym, że badania Holzera są częściowo nieaktualne, niepełne. Co na pewno zostanie to moje geny, to znaczy troje dzieci, czworo wnuków, to na pewno zostanie, to jest dorobek niewątpliwy na przyszłość.

Natomiast chciałbym powiedzieć, co było najciekawsze dla mnie w tym osiemdziesięcioleciu? Ja myślę, że najciekawsze były spotkania z ciekawymi ludźmi, kontakty z ciekawymi ludźmi. Nie chcę mówić o obecnych tu, bo obecni są wszyscy ciekawymi ludźmi, jak zacznę wymieniać, to nie skończę, chciałbym mówić o tych, których tu nie ma, których nie ma już na tym świecie. Spis ciekawych ludzi, z którymi przyszło mi się spotykać: na studiach z Bronkiem Geremkiem, po studiach z Benedyktem Zientara, z Antkiem Mączakiem, z Henrykiem Samsonowiczem. Osoby, z którymi się spotkałem najpierw jako student i później: Witold Kula i Leszek Kołakowski, na jego zajęcia chodziłem na pierwszym roku studiów. A i później było wiele ciekawych osób, które spotkałem. Myślę, że tak się złożyło, że może najciekawszą grupą była redakcja "Poglądów”, było to takie mało znane czasopismo, nielegalne oczywiście, $\mathrm{z}$ lat osiemdziesiątych i tam byliśmy razem $\mathrm{w}$ redakcji z Leszkiem Balcerowiczem, z Jackiem Tarkowskim, wspaniałym socjologiem polityki, i Krzysztofem Wolickim. To byli naprawdę ciekawi ludzie. Jeszcze oczywiście Tadeusz Mazowiecki. Ci ciekawi ludzie to też kilku niemieckich przyjaciół Heiner Winkler, Helmut Wagner, Gesine 
Schwan. To jest grono moich niemieckich przyjaciół, bardzo ciekawych ludzi. I myślę, że to jest to, co czyni ciekawym osiemdziesięciolecie, że można mieć tego rodzaju kontakty, znajomości, przyjaźni. Dziękuję.

\section{Profesor Piotr Madajczyk}

Przechodzimy teraz do drugiej części naszej uroczystości. O refleksje zostały poproszone trzy osoby, dwie z Niemiec, jedna z Polski. Nie ma tu wprawdzie parytetu, ale chodzi o refleksje, a nie o parytety. Każda z zaproszonych osób zajmuje się, aczkolwiek w różnych obszarach, sprawami polsko-niemieckimi. Nie udało się zaprosić wspominanej dzisiaj pani profesor Schwan, pozostali jedynie męscy uczestnicy. Założenie było takie, aby zabrały głos osoby, zajmujące się różnymi obszarami, związanymi z zainteresowaniami Jubilata. Prof. Friszke zajmuje się najnowszą historią Polski, w tym opozycją prof. Ziemer, były dyrektor Niemieckiego Instytutu Historii w Warszawie - silniej historią stosunków polsko-niemieckich. Prof. Bingen jest politologiem i dyrektorem Niemieckiego Instytutu Polskiego w Darmstadt. Mamy więc dwóch politologów i jednego historyka.

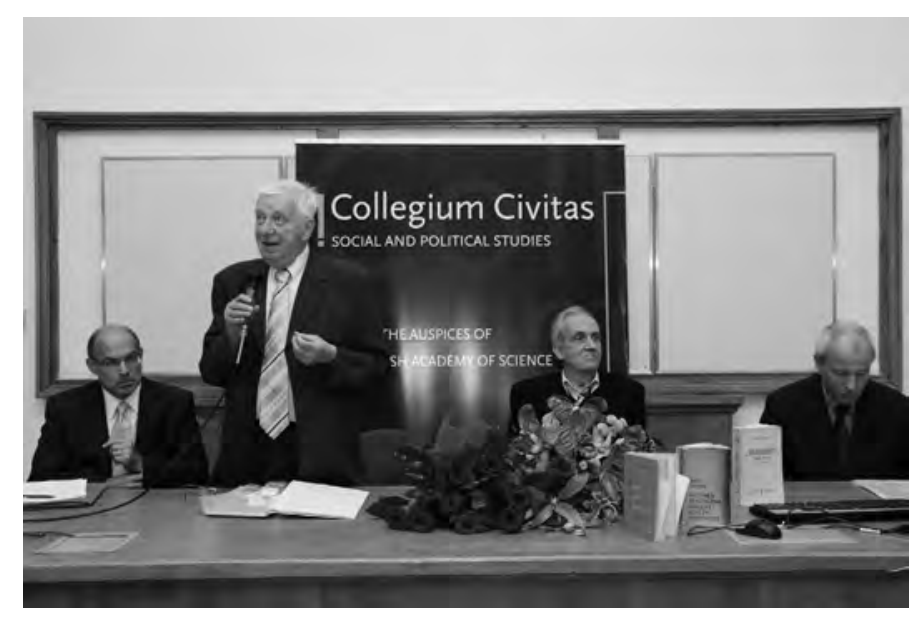

\section{Profesor Dieter Bingen}

Dziękuje bardzo. Szanowny Jubilacie, szanowni Państwo. Chciałbym się z Państwem podzielić kilkoma refleksjami, jako Niemiec, Europejczyk i kolega Jubilata, wywodzący się z generacji powojennej. 
Jak spojrzeć na osobę Jubilata? Przygotowując się do dzisiejszego spotkania, pytałem się: Co jest Jerzego Holzera przewodnią nicią życia naukowego, a może i osobistego? Może są to dramatyczne doświadczenia z pierwszego dwudziestolecia Jego życia. Jubilat był świadkiem, obserwatorem i naukowym analitykiem dramatycznych czasów, które przechodziła jego Ojczyzna i Europa. Był obserwatorem i świadkiem życia politycznego swego kraju i społeczeństwa pod kuratelą władzy komunistycznej. To można dostrzec w jego pracy naukowej. Był on i jest człowiekiem z wartościami humanistycznymi i demokratycznymi.

Profesor Holzer obserwował i badał współżycie różnych kultur, narodów i religii w jednym kraju i w cywilizacji europejskiej. Przewodnią nić jego zainteresowań stanowi ta ich różnorodność, jako fundament dziejów, kultury, przetrwania i cywilizacji polskiej i europejskiej (Polska i Europa w Polsce albo nigdzie, 2008). Doświadczenia osobiste Jubilata i doświadczenia zbiorowe społeczeństwa polskiego - czy było inne wyjście niż bycie gorącym zwolennikem praw człowieka i obywatela, niż być solidarnym $\mathrm{z}$ innymi?

Jego naukowy dorobek w języku polskim czy niemieckim, czy angielskim można byłoby długo cytować. Są też odzwierciedleniem wrażliwości naukowej Jerzego Holzera. Teraz cytuje tylko pracę zbiorową dotyczącą Niemców, Polaków i Żydów i ich współżycia od oświecenia do początku II wojny światowej (Robert Maier, Georg Stöber, red., Deutsche, Polen und Juden. Schauplätze ihres Zusammenlebens von der Zeit der Aufklärung bis zum Beginn des Zweiten Weltkriegs, 1996). W tym zbiorze znajduje się artykuł Jubilata o Żydach galicyjskich, między niemieckością i polskością (oryg: Die galizischen Juden. Deutschtum und Polentum. Zwischen Abgrenzung und Assimilation). Inna jego praca w języku angielskim dotyczy stosunków polskich partii politycznych do antysemityzmu w Polsce międzywojennej (w: Polin. Studies in Polish Jewry, 2004). Poza tym istnieje całe multum jego artykułów dotyczących demokracji oraz klęski demokracji w Polsce międzywojennej. Zmiana perspektywy badawczej Jubilata była widoczna w jego wielkiej i doskonałej książce o Europie wojennej w latach 1914-1945, napisanej z perspektywy ofiar, cierpienia żołnierzy, jeńców, godności cywilnej, więźniów w obozach koncentracyjnych, wypędzonych i wysiedlonych. Najważniejsze książki 
Jubilata o polityce europejskiej w XX wieku są tłumaczone na język niemiecki czy też $\mathrm{w}$ tym samym czasie wydawane w Polsce i w Niemczech - w języku polskim i języku niemieckim.

Życie Jubilata czyni z niego gorącego zwolennika praw obywatelskich i praw człowieka - zwolennika ładu społecznego i politycznego, człowieka solidaryzującego się ze wszystkimi obywatelami nie tylko swojego kraju, ale całej Europy. Wymieniane było już Polskie Porozumienie Niepodległościowe, forum dyskusyjne, w którym już w 1978 roku sformułowana została teza, że Polska droga do Europy prowadzi razem z Niemcami. Być może nawet zjednoczenie Niemiec może być korzystne i dla Polski. W tamtych czasach teza ta nie znalazła oddźwię$\mathrm{ku}$, nawiązano do niej dopiero pod koniec lat osiemdziesiątych zeszłego wieku, a przecież stanowiła ona $\mathrm{w}$ tamtych czasach w stosunkach polsko-niemieckich fenomen. Dalej: Napisał otwarty list ważny dla dialogu polsko-rosyjskiego w 1988 roku, a w grudniu 1987 roku list otwarty do Lecha Wałęsy i Wojciecha Jaruzelskiego. Był i jest człowiekiem dialogu, patrzy z empatią na sprawy polsko-niemieckie. Angażował się w dyskusje o utworzeniu europejskiego centrum przeciw wypędzeniom, gdy na początku tego wieku problem ten nie był tak zinstrumentalizowany jak w ostatnich latach.

Dla mnie Profesor Holzer na zawsze pozostanie związany z ideą Solidarności przez małe i wielkie "S". Walczył czynnie z narodowymi fobiami, autorytaryzmem, dyktaturą. Realizował to w badaniach nad historią Polski międzywojennej, a także angażując się w idee Solidarności. Realizował to w swoich analizach historii komunizmu, która to idea równości i równych szans, jaką była jako idea, została tak brutalnie skarykaturyzowana w praktyce. Jego książka opublikowana w językach polskim i niemieckim jest wydana przez Federalną Centralę Kształcenia Politycznego (Bundeszentrale für politische Bildung), tzn. dla demokratycznego kształcenia młodych Niemców. Jerzy Holzer jest autorem książki o „Solidarności”, pierwszej rzetelnej i obiektywnej analizy ruchu solidarnościowego, niezmiernie ważnej i cennej. Książka ta opublikowana została w Republice Federalnej Niemiec w 1985 roku, ukazywała klęski ruchu i najważniejsze wydarzenia, które w końcu zmieniły gruntownie oblicze Polski, Niemiec, Rosji i Europy. 
Pierwszy raz spotkałem się z Panem Profesorem w czerwcu 1989 roku w mieszkaniu pani profesor Gesine Schwan w Berlinie, chciałem przeprowadzić z Panem Profesorem wywiad dotyczący stosunków polsko-niemieckich oraz zmian w Europie dla niemieckiego czasopisma katolickiego. To, co dla mnie w czasie tego wywiadu było bardzo typowe, to Pańska rzetelność naukowa, skrupulatność, ostrożność w ocenie sytuacji. Pański sceptycyzm, ale także przejrzystość i jasność w osądach były dla mnie godne podziwu, a poza tym jego sposób artykulacji argumentów był bardzo przekonujący. To tylko kilka refleksji osobistych.

\section{Profesor Andrzej Friszke}

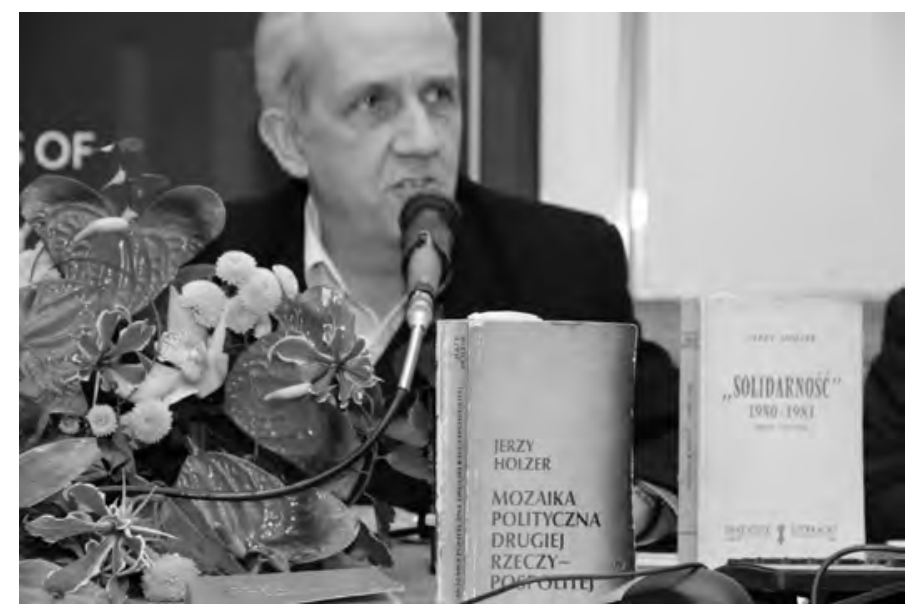

Proszę Państwa, przyniosłem i postawiłem tu na stole trzy książki Profesora Holzera, które w moim przekonaniu są ważnymi punktami jego ogromnego dorobku. Być może jedna jest Państwu mało znana, bo dosyć dawno została wydana, a właśnie od niej chciałbym zaczać. Mianowicie: Polska Partia Socjalistyczna w latach 1917-1919, rok wydania 1962. Profesor Holzer w swoim życiu wielokrotnie zajmował się PPS i napisał syntezę dziejów tej partii. Ale ta książka, pierwsza książka późniejszego Profesora Holzera jest czymś, nad czym warto się zastanowić. Jest pewnego rodzaju deklaracją przywiązania do tradycji PPS i jest jedną z pierwszych książek dotyczących Dwudziestolecia, które wyszły 
w powojennej Polsce i miały walor naukowy. Była monografią, która zawierała autentyczną treść, niosła wartość informacyjną dotyczącą i roku 1918, i PPS w latach 1917-1919, czyli okresu bezpośredniej genezy odbudowania państwa. Narracja kończy się parę miesięcy po powstaniu Polski Niepodległej, więc jest to książka również o powstaniu Polski Niepodległej. O tym, jak w najważniejszym w tym czasie, w twórczym działaniu na rzecz niepodległości Polski jesienią roku 1918, partia, której politykiem był premier, reagowała, jak się zachowywała. Książka, która jest $\mathrm{w}$ też $\mathrm{w}$ pewnym sensie sprawozdaniem dotyczącym odniesienia się socjalistów do problemu bolszewików, do problemu rewolucji październikowej 1917. Dlatego jest ważna.

Jest to książka istotna ze względu na metodologię, której Profesor Holzer był później wierny. Tą metodologię stosowało stosunkowo wielu historyków, zajmujących się historią najnowsza, a wyrażała się ona w koncentracji na faktach. Metodologia opowiadania czytelnikowi historii przez omawianie kolejnych zdarzeń, wypowiedzi, działań, kontrowersji, przy minimalizowaniu komentarza autora. Autor nie dąży do wielkich syntez, nie dąży do uogólnień, ocen, jest w tym zakresie ostrożny, a prowadzi czytelnika przez opowieść o faktach. Była to też metoda walki z cenzura dość skutecznej walki, bo cenzurze trudniej było negować fakty czy cytaty niż ogólne stwierdzenia autora.

To jest, jak powiedziałem, pierwsza książka. Druga książka, którą tutaj postawiłem, była wielokrotnie wspomniana podczas dzisiejszego spotkania. Mozaika polityczna II Rzeczypospolitej. Rok wydania 1974. To jest książka, która wśród opracowań dotyczących II Rzeczypospolitej jest niezwykle ważna. Wśród prac dotyczących II Rzeczypospolitej, które wtedy powstały, zajmuje miejsce szczególne poprzez pokazanie całego wachlarza polskiego życia politycznego, od prawicy do skrajnej lewicy, oraz obejmuje nie tylko partie polskie, ale także partie mniejszości narodowych. Zostało wspomniane, i bardzo słusznie, że Profesor Holzer zwraca uwagę na pluralizm w II Rzeczypospolitej. Książka była jedną z pierwszych pozycji monograficznych, które szeroko omawiały nie tylko polskie partie polityczne, a wiedza o nich była niewielka, ale też żydowskie, niemieckie, ukraińskie, białoruskie. Jest to książka, która w moim przekonaniu do tej pory zachowuje wartość przez kom- 
petentne omówienie bogactwa życia politycznego, ideologii, struktur organizacyjnych. Nie ma niczego porównywalnego do dnia dzisiejszego.

Ta książka, jak mi się wydaje, w pewnym sensie zamykała badania Jerzego Holzera nad II Rzeczpospolita, otwierając je jednocześnie w innych kierunkach. Choć przecież pozostawało także seminarium magisterskie i seminarium doktoranckie na uniwersytecie. W seminarium magisterskim miałem przyjemność uczestniczyć w końcu lat siedemdziesiątych, i to było niezwykłe seminarium. Również dlatego, chcę to przypomnieć w tym momencie, że polegało na tym, iż czytaliśmy, a potem omawialiśmy różne ważne teksty polskiej myśli politycznej. Czytaliśmy Różę Luksemburg i Dmowskiego, czytaliśmy socjalistów i czytaliśmy ludowców, i oczywiście piłsudczyków. Jednym słowem ten przegląd, te analizy koncepcji politycznych, myśli politycznych kształtowały horyzont refleksji o sprawach polskich i o sprawach powszechnych, bo również o ideach, które miały charakter powszechny.

W końcu lat siedemdziesiątych, jak tu zostało powiedziane, Profesor Holzer przesuwał badawcze zainteresowania w kierunku Polski powojennej. To jest czas niedużego opracowania wydanego w „Krytyce” pod pseudonimem „Wacław Pański”, liczącego nie więcej niż dwadzieścia, dwadzieścia parę stron druku. Ale jest ono w moim przekonaniu jednym z najważniejszych do dzisiaj tekstów, dotyczących pierwszych lat powojennych. Myślę o tekście Z dziejów PPS (1944-1948) z dodatkiem kilku ważnych dokumentów, ilustrujących sposób myślenia przywódców tej partii w takiej sytuacji, w jakiej znajdowała się Polska w latach 1944-1948. Nie ma do tej pory, poza wydanymi w PRL-u takimi syntezami ocenzurowanymi - zewnętrzna cenzura, wewnętrzna cenzura - opracowań dotyczących tej partii. To opracowanie jest też swego rodzaju polemiką $\mathrm{z}$ historią schematyczna, $\mathrm{z}$ historia, która łatwo dzieli postawy na słuszne bądź niesłuszne, na heroizm i zdradę. Tu jest pokazany dylemat tamtego czasu, dylematy polityki, w której nie było dobrych wyborów.

W tym też czasie Profesor Holzer należał do współzałożycieli seminarium prywatnego, które zaczęło się zajmować w sposób systematyczny historią powojenną próbując studiować dokumenty i przesłuchiwać 
świadków. Seminarium powstało z inicjatywy Adama Michnika, uczestniczyli w nim Krystyna Kerstenowa, Maria Turlejska, Jerzy Holzer, Andrzej Paczkowski, Jan Kofman, Maciej Koźmiński, w latach późniejszych Anna Radziwiłł i ja. Seminarium trwało przez dobrych dziesięć lat i tam wykuwały się w różnych dyskusjach ważne monografie czy wydawnictwa źródłowe, dyskutowano problemy oraz metodologię badań nad okresem powojennym. Były to początki szukania metodologii, sposobu patrzenia na tamte czasy, na tamtą epokę, formułowania pytań, które owocowały już w latach osiemdziesiątych i po roku 89 całym szeregiem ważnych publikacji monograficznych, a także dokumentacyjnych.

Myślę, że kiedy mówimy o książce Solidarność. Geneza i historia to ta metodologia jest widoczna. Jest to próba opisania podmiotów działających w sposób możliwie analityczny, nie emocjonalny, nietraktujący opisu historycznego jako walki o słuszność naszej sprawy, jako polemiki z przeciwnikiem, przy podkreśleniu jednak wartości, za którymi autor się opowiada. Ta książka, o której chcę jeszcze parę słów powiedzieć, jest monografią szczególnie ważną. Proszę Państwa, twierdzę, że ona jest nadal najważniejszą książką o Solidarności, mimo że upłynęło dwadzieścia parę lat, i mimo że była pisana na gorąco. Pamiętam dobrze, wówczas Profesor Holzer wrócił z obozu z internowania, w swoim warszawskim mieszkaniu na Żoliborzu miał pełno rozłożonych biuletynów związkowych i prowadził analizę tych pism. To było pisane zupełnie na żywo, patrole chodziły po ulicach, autor miał jeszcze brodę, którą zapuścił w obozie internowania. Był to czas pisania książki o czymś, co było niezmiernie żywe, aktualne i bolesne, a zarazem pisania $\mathrm{w}$ taki sposób, że to nie jest propaganda, że to jest rzecz zachowująca wartość analizy dokonywanej przez chłodny umysł, zdolny do rekonstrukcji, dostrzegania sporów po naszej stronie i po tamtej stronie, do analizy dokumentów programowych. Zresztą namawiałem Profesora Holzera, żeby ją wydać po raz wtóry w latach dziewięćdziesiątych, do czego nie doszło, ale ja się upieram przy swoim, że ona nadal jest warta wydania, mimo ujawnienia od tego czasu różnych dokumentów sowieckich, niemieckich, ubeckich i innych. Oczywiście, ta wiedza się poszerzyła i nadal się poszerza, być może warto dodać rozdział o relacjach polsko- 
-sowieckich. Gdyby tak się stało, to ten rozdział potwierdzi intuicję bardzo mocno obecną w tej książce, ale nie doprowadzi do weryfikacji jakiś istotnych tez. To była wielka sztuka wyczucia realiów tamtego czasu i, bym powiedział, świadectwo niezwykłego mistrzostwa.

Proszę Państwa, w latach późniejszych Profesor Holzer zajmował się bardziej historią powszechną niż historią Polski, w związku z tym ja już nie będę zanadto o tym mówił, zostawię to współuczestnikom dyskusji. Natomiast zamykając to, co chciałem powiedzieć, dodam, że niewątpliwie jest dla nas zaszczytem, że znaliśmy i mogliśmy współpracować z Jerzym Holzerem, który z całą pewnością należy do najważniejszych polskich powojennych historyków i który budował historię w XX wieku w tym jej naprawdę znakomitym nurcie, który decyduje o tym, że jest to naprawdę kawał solidnej nauki. Dziękuję.

\section{Profesor Jerzy Holzer}

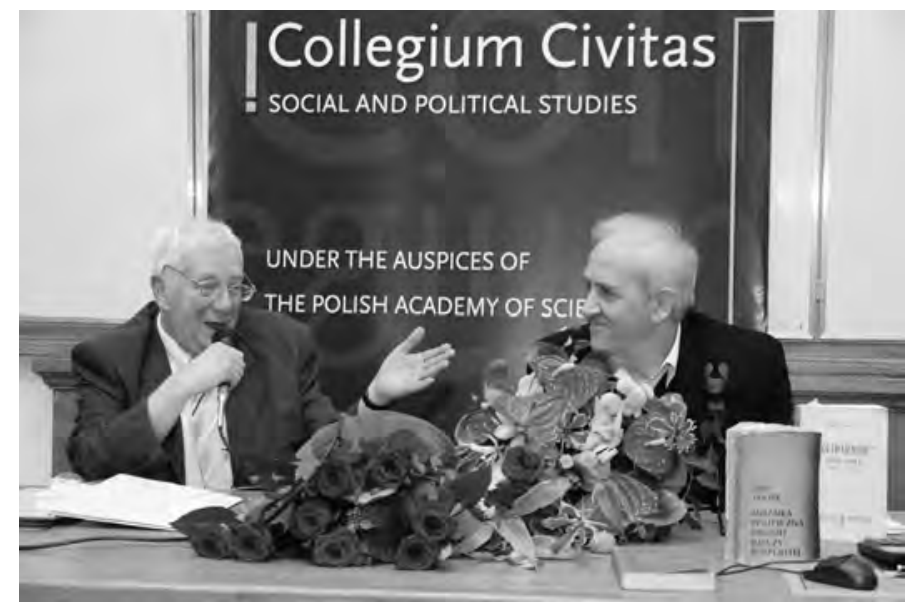

Jeśli można włączyć tutaj dwie anegdoty. Pierwsza, dotycząca książki o "Solidarności”. Andrzej Friszke postawił tu wydanie emigracyjne. Był to bardzo ciekawy przypadek, mianowicie mój wydawca Jan Kofman potrafił ją w kraju szybciej wyprodukować aniżeli zrobiono to w Paryżu. „Książę" miał pretensję, że książka najpierw wyszła w kraju, bo nigdy nie wydawał książek uprzednio już wyprodukowanych, ale książka nie mogła przecież czekać. To taka pierwsza anegdota, 
a druga - ta Mozaika, ten tytuł dostała po prostu od cenzury. Tak naprawdę miał brzmieć „Partie polityczne II Rzeczpospolitej - zarys dziejów", ale cenzura zdecydowała, że za mało jest o komunistach i tytuł musi być mniej obowiązujący. Innymi słowy, jest to cenzurowany tytuł, tak się zdarzało.

\section{Profesor Klaus Ziemer}

Drogi Jubilacie, szanowni Państwo, po tylu przedmówcach bardzo trudno mówić jeszcze coś tak oryginalnego. Myśląc o Jerzym Holzerze widzę z jednej strony wielkiego uczonego i działacza opozycji w Polsce oraz autorytet, wręcz instytucję w stosunkach polsko-niemieckich. Przynajmniej od lat siedemdziesiątych Jerzy Holzer był osobą pierwszego kontaktu dla wielu naukowców niemieckich, którzy szukali kompetentnych ekspertów w rożnych dziedzinach nauk społecznych w Polsce. Sam gościł na różnych uniwersytetach niemieckich, w dalszym ciągu jest poszukiwaną osobą na konferencjach w Polsce, w Niemczech i wielu innych krajach. Od połowy lat siedemdziesiątych był orędownikiem porozumienia polsko-niemieckiego, a nikt nie zdziwiłby się, gdyby zajął zupełnie inną postawę wobec Niemiec. Już była mowa o tym, ale nie sposób jeszcze raz nie wspomnieć o tym, co Jerzy Holzer i jego rodzina przeżyli podczas okupacji niemieckiej. Jerzy Holzer prawie nigdy o tym nie wspomina, tylko raz o tym słyszałem parę lat temu podczas poruszającego przemówienia $\mathrm{w}$ rezydencji ambasadora niemieckiego w Warszawie z okazji odznaczenia Jubilata Wielkim Krzyżem Orderu Zasługi Republiki Federalnych Niemiec. Jeden z polskich naukowców, który krótko po publikacji swoich wspomnień z czasów wojennych uczestniczył wraz ze mną na konferencji w Warszawie, pokazał mi budynek na ulicy, w którym on i Jerzy Holzer mieszkali podczas okupacji. Ciągle myślę o tym, będąc na tamtej uczelni, że pomimo strasznych doświadczeń ze strony niemieckiej szukał Jubilat w trudnych warunkach politycznych możliwości porozumienia polsko-niemieckiego przede wszystkim w środowisku historyków. Nic dziwnego, że później staje się członkiem wspólnej komisji polsko-niemieckiej. Komisja wiele zrobiła na rzecz wzajemnego porozumienia między naszymi narodami. 
Była już o tym mowa, że Jubilat był bardzo aktywnym obywatelem, zaangażowanym działaczem opozycji i był internowany. Napisał historię "Solidarności”, książka wyszła w kraju w podziemiu w 1983 roku. Została ona przetłumaczona na język niemiecki. W 1980 roku książka wyszła w monachijskim wydawnictwie i była pierwszą książką po niemiecku, która tak obszernie przedstawiała historię "Solidarności" lat 1980-1981.

Śledzenie śladów Jerzego Holzera w latach osiemdziesiątych było dla cudzoziemca fascynującą obserwacją aktualnej polityki Polski. List otwarty Jubilata z 13 grudnia 1987 roku do gen. Jaruzelskiego i Lecha Wałęsy, zrobił wówczas na mnie ogromne wrażenie, tym bardziej że został opublikowany równocześnie w „Polityce” i nielegalnym tygodni$\mathrm{ku}$ „Mazowsze”. Dla Niemca kojarzyło się to z sytuacją w NRD, gdzie takie wydarzenie po prostu byłoby niemożliwe. Czytając dzisiaj w tym liście porównanie Jerzego Holzera sytuacji Polski w drugiej połowie lat osiemdziesiątych z sytuacją Polski pod koniec XVIII wieku, widzimy, w jaki sposób pozycja międzynarodowa Polski zmieniła się od tego czasu. Zmienił się również kształt gałęzi nauk społecznych w Polsce, powstał Instytut Studiów Politycznych, który mieścił się przez pewien czas na 17. piętrze w Pałacu Kultury i Nauki. Byłem tam wówczas kilka razy gościem i nie miałem najmniejszego pojęcia, że parę lat później miało tam się znaleźć moje własne miejsce pracy w Niemieckim Instytucie Historycznym. Jerzy Holzer został kierownikiem Zakładu Studiów nad Niemcami Instytutu Studiów Politycznych, o tym też już była mowa, zachęcał do współpracy znakomitych naukowców, stworzył znakomity zespół fachowców i wychował grono uczniów, którzy dzisiaj sami są profesorami lub zajmują wybitne miejsce w życiu polityczno-społecznym.

Dziś słyszeliśmy o jednym z uczniów Jubilata, który został ambasadorem Polski za granicą. Ja znam przynajmniej dwóch innych polskich ambasadorów, którzy są uczniami Jerzego Holzera.

Jubilat założył - ukazujący się od roku 1992 - „,Rocznik Polsko-Niemiecki", w którym wypowiadają się polscy i niemieccy eksperci zajmujący się i specjalizujący w różnych aspektach stosunków polsko-niemieckich, zwłaszcza polityką i historią współczesną naszych krajów. 
Wraz ze zmianą systemową w Polsce w 1989 roku Jerzy Holzer przyjął w sposób naturalny po polskiej stronie kierownictwo najważniejszej instytucji polsko-niemieckiego dialogu obywatelskiego, co podkreślało dobitnie jego autorytet $\mathrm{w}$ sprawach polsko-niemieckich. Było sprawą prawie oczywista, że kiedy w 1993 roku powstał w Warszawie Niemiecki Instytut Historyczny, to Jerzy Holzer został zaproszony do jego Rady Naukowej i był jego członkiem przez dwie kadencje. Był też członkiem organu, który nadzorował też moją działalność, gdy od roku 1998 pracowałem w tej instytucji. Zawsze towarzyszył on działalności Instytutu z wielkim zainteresowaniem i życzliwością. $W$ stosunkach polsko-niemieckich w dziedzinie nauki, szczególnie od czasu przełomu politycznego, Jerzy Holzer był przede wszystkim inspiratorem i organizatorem badań naukowych dotyczących różnych aspektów stosunków polsko-niemieckich i rozwoju oraz ładu ogólnoeuropejskiego. Świadczą o tym m.in. różne tomy wspomnianego "Rocznika Polsko-Niemieckiego”. Aktywnie działał, wręcz był wszechobecny, w środowisku polsko-niemieckim. Jerzy Holzer był wziętym, poszukiwanym polskim uczestnikiem projektów naukowych. Często bywał w Niemczech. Kiedyś powiedział mi, będąc w Niemczech, że dzisiaj wszystkie loty w obrębie Europy trwają nie więcej niż 1 godzinę, nie tylko dotyczy to lotów do Niemiec, ale i do Francji czy Anglii, gdzie również ukazywały się jego publikacje. Kiedyś także spotykałem Go niespodziewanie w Berlinie na lotnisku. Nie ograniczał on swojej działalności tylko do stosunków naukowych, ale również przyjmował zaproszenia od publiczności nienaukowej w Niemczech. Przyjechał np. w latach dziewięćdziesiątych do bardzo aktywnego, ale położonego na głębokiej prowincji niemieckiej, Stowarzyszenia polsko-niemieckiego, aby tam przemawiać o stosunkach polsko-niemieckich przed dużym audytorium. Wzmacniał $\mathrm{w}$ ten sposób stosunki polsko-niemieckie, wspierał tych Niemców, którzy pracowali na rzecz lepszego porozumienia polsko-niemieckiego w społeczeństwie niemieckim. Największy wpływ miały jego własne publikacje, te prace są tak liczne, że nie sposób je wszystkie wymienić. Zrobili to po części Andrzej Friszke i Dieter Bingen. Ja nie będę recenzentem prac Jerzego Holzera. Chciałbym jedynie powiedzieć, patrząc na dorobek Jerzego Holzera, tylko ten $z$ ostatniej dekady, jestem pe- 
łen podziwu, ale muszę też powiedzieć, że mam pewne oczekiwania, co do następnych lat. Drogi Jubilacie, życzę Tobie wszystkiego, co najlepsze.

\section{Jan Skórzyński}

Ja chciałbym zabrać głos, aby wspomnieć o jeszcze jednej dziedzinie badawczej profesora Jerzego Holzera, o której tutaj się dosyć mało mówiło - mianowicie badań nad faszyzmem i totalitaryzmem. Miałem honor być członkiem seminarium magisterskiego u profesora Holzera w latach 1978-80, było to jedno z niewielu seminariów historii powszechnej w naszym Instytucie, oprócz tego Profesor prowadził też seminarium z historii Polski, na którym było całe mnóstwo osób, co najmniej 20, na naszym zebrało się osób 3 - było to prawdopodobnie spowodowane dosyć ostrym warunkiem wstępnym, jaki Profesor postawił, mianowicie znajomości przynajmniej jednego języka obcego. Znalazło się nas trzech i było to korzyścią dla tych, którzy się znaleźli w tym gronie, bo mieliśmy dużo czasu na dyskusje na temat dzieł takich historyków jak: Mosse czy Rence de Felice. To wszystko prowadziło w sposób nieunikniony w stronę totalitaryzmu, porównań pomiędzy komunizmem a faszyzmem czy nazizmem, w latach 1979-80 były to dyskusje na Uniwersytecie Warszawskim prowadzone bez żadnych barier cenzuralnych. Pan Profesor nawet zostawiał nam w czytelni trudno dostępne pozycje z jego własnej biblioteki, nie kryjąc się z tym zupełnie. Miałem wówczas poczucie, że jest to kawałek swobodnego świata naukowego, badawczego. Sam poszedłem na seminarium nie tylko ze względu na zainteresowania akurat faszyzmem, ale tym, co najbardziej mnie wtedy interesowało, a więc dziejami PRL-u, komunizmu w Polsce. Okazało się, że przygotowanie z faszyzmu, totalitaryzmu było świetnym wstępem do badań nad PRL-em. Profesor Holzer poświęcał nam dużo czasu i wysłuchiwał naszych refleksji na tematy, na które znaliśmy się o wiele mniej niż On, natomiast nie był szalenie skrupulatnym promotorem prac magisterskich i na szczęście na temat naszych prac magisterskich rozmawialiśmy bardzo niewiele. Pamiętam, że w roku 1981, ja skończyłem studia w 1980 roku, jak zwykle bywa długo mi szło napisanie pracy, spotkałem Profesora. Już nie byłem studentem, zajmowałem się rewolucją i Profesor przesłał mi karteczkę na sesji 
naukowej w Poznaniu o Czerwcu 1956, przy okazji otwarcia pomnika, że egzamin magisterski ma Pan dnia tego... W ten sposób przypomniał mi, że jest coś jeszcze poza tą rewolucją, a następnym razem spotkaliśmy się 13 grudnia w Białołęce. Dziękuję bardzo.

Na tym zakończyła się oficjalna część Jubileuszu, a jego uczestnicy kontynuowali rozmowy przy filiżance kawy i kieliszku wina. Redakcja „Rocznika Polsko-Niemieckiego" składa Jubilatowi serdeczne życzenia zdrowia, dalszych owocnych lat pracy i kolejnych książek, na które czekamy z ciekawością. 